\title{
HETEROGENEOUS GROWTH IN FINGERLINGS OF THE NILE TILAPIA Oreochromis niloticus: EFFECTS OF DENSITY AND INITIAL SIZE VARIABILITY
}

\author{
BARBOSA, J. M. ${ }^{1}$, BRUGIOLO, S. S. S. ${ }^{2}$, CAROLSFELD, J. ${ }^{3}$ and LEITÃO, S. S. ${ }^{4}$ \\ ${ }^{1}$ Departamento de Pesca e Aqüicultura, Universidade Federal Rural de Pernambuco, Recife, PE, Brazil \\ ${ }^{2}$ Instituto de Biociências, Universidade Federal de Juiz de Fora, Juiz de Fora, MG, Brazil \\ ${ }^{3}$ World Fisheries Trust, Victoria, B. C., Canada \\ ${ }^{4}$ Fundação Apolônio Sales de Desenvolvimento Educacional \\ Correspondence to: José Milton Barbosa, Departamento de Pesca e Aqüicultura, \\ Universidade Federal Rural de Pernambuco, Av. Dom Manuel de Medeiros, s/n, CEP 52171-900, \\ Dois Irmãos, Recife, PE, e-mail: jmiltonb@gmx.net \\ Received September 20, 2004 - Accepted December 6, 2004 - Distributed May 31, 2006
}

(With 2 figures)

\begin{abstract}
In this study, the effect of initial heterogeneity of weight and density on heterogeneous growth (HetG) evaluated by the coefficient of the variation of weight in the young Nile tilapia Oreochromis niloticus of the territorial species was tested. Fish were maintained in a glass aquarium ( 8 and $2 \mathrm{~L}$ of water) with two levels of initial heterogeneity of weight: low and high, under two density conditions: low and high, thus constituting four conditions (six replications for each). Initially, the weights of the animals were taken after 8, 16, 22 and 30 days (end of experiment). The results, evaluated by the non-parametric test of Kruskal-Wallis, demonstrated that in the groups where the animals were stored under high initial HetG, there was a reduction of the same and that in the groups where the animals were stored under high density, there was exacerbation or maintained high values of HetG. High density in association with high initial heterogeneity caused more exacerbation of $\mathrm{HetG}$ in such a way that the density appeared to be a determining factor for exacerbation or the maintenance of high values of HetG, whereas the initial heterogeneity of the weight could be a secondary factor.
\end{abstract}

Keywords: fish, behavior, density, heterogeneous growth.

\section{RESUMO \\ Crescimento heterogêneo em juvenis de Tilápia-do-nilo Oreochromis niloticus: efeito da heterogeneidade inicial de peso e da densidade}

Neste trabalho, testou-se o efeito da heterogeneidade inicial de peso e da densidade sobre o crescimento heterogêneo (CHet, avaliado pelo coeficiente de variação do peso) em juvenis de tilápia-do-Nilo Oreochromis niloticus, espécie territorial. Os peixes foram mantidos em aquários de vidro (8 e 2 L d'água) com dois níveis de heterogeneidade inicial de peso: baixo e alto, sob duas densidades: baixa e alta, configurandose quatro condições (6 réplicas cada uma). Os pesos dos animais foram tomados no início, aos 8, 16, 22 e 30 dias (final do experimento). Os resultados, avaliados pelo teste não paramétrico de Kruskal-Wallis, demonstraram que nos grupos em que os animais foram estocados com alto CHet inicial houve redução e que nos grupos em que os animais foram estocados em alta densidade houve exacerbação ou manutenção dos altos valores de CHet. A alta densidade quando associada à alta heterogeneidade inicial provocou maior exacerbação do CHet de forma que a densidade parece ser um fator determinante da exacerbação ou da manutenção de altos valores de CHet, enquanto a heterogeneidade inicial de peso pode ser um fator secundário.

Palavras-chave: peixe, comportamento, densidade, crescimento heterogêneo.

Braz. J. Biol., 66(2A): 537-541, 2006 


\section{INTRODUCTION}

Heterogeneous growth (HetG) is different in growth rates among conspecific and occurs even among individuals of the same age (Wolhfarth, 1977). Although some authors attribute it to increased growth of some animals in relation to others (Wolhfarth, 1977), in many species it is a result of reduced growth of most of the individuals in the population (Allen, 1972; Jobling \& Wandisvich, 1983; Koebele,1985; Davis \& Olla, 1987; Volpato \& Fernandes, 1994) resulting in decreased fish production.

Although HetG has been reported for several fish species and other animals, little is known about its causative mechanisms. Lack of adequate food, genetic and population factors have all been suggested, including social interactions during crowding (Brown, 1946; Koebele, 1985; Volpato \& Fernandes, 1994). Several authors have reported that HetG in fish is intensified by crowding (Brown, 1946; Nakamura \& Kasahara, 1955; 56; 57 e 61; Yamagishi, 1969; Wohlfarth, 1977; Volpato et al., 1989; Fernandes \& Volpato, 1994; Barbosa, 1997). However, most of these studies have been carried out with initial fish groups selected in terms of homogeneous sizes. In contrast, Ito \& Barbosa (1996) stocked juveniles of mullet, Mugil platanus with high initial variability in size and low densities and noted a reduction in HetG. The authors suggested that specific studies should be conducted to better evaluate this phenomenon.

The aims of the present study are to examine the effects of rearing density and initial heterogeneity of fish sizes on heterogeneous growth in the presence of excess food, using the Nile tilapia Oreochromis niloticus as an experimental model.

\section{MATERIAL AND METHODS}

\section{Animals and holding conditions}

The study was carried out in the Laboratório de Aqüicultura of the Faculdade de Zootecnia e Engenharia de Alimentos, situated in the Campus of the Universidade de São Paulo, Pirassununga, State of São Paulo, Brazil. Ninety-six fingerlings of Oreochromis niloticus from a single spawning were raised together in an $8 \mathrm{~m}^{3}$ cement tank for two months to an approximate weight of $5 \mathrm{~g}$, each at a density of 0.8-1.2 fish/L. Experiments were carried out in glass aquaria of $8 \mathrm{~L}(25 \times 30 \times 20 \mathrm{~cm})$. Three of these were permanently partitioned with sheets of opaque polyvinyl chloride to provide four $2 \mathrm{~L}$ containers for high density treatments. Groups of four fish each were selected from this stock at the beginning of the experiment (see below) and transferred to 12 full sized aquaria for low density treatment and 3 partitioned aquaria (12 groups) for high density treatment. The aquaria received constant water flow $(5 \mathrm{~mL} / \mathrm{s})$ at room temperature $\left(26-28{ }^{\circ} \mathrm{C}\right)$. Fish were fed ad libitum every day with a pelleted commercial diet and detritus and excreta were removed from the aquaria every two days with a siphon. The temperature and $\mathrm{pH}$ of the water were monitored daily, whereas dissolved oxygen, nitrite, and ammonia were measured twice a week.

\section{Experimental design}

Four courses of treatment were studied:

- 1 = low initial size variability and low stocking density;

- 2 = high initial size variability and low stocking density;

- 3 = low initial size variability and high stocking density; and

- 4 = high initial size variability and high stocking density.

The initial size variability was assessed as the coefficient of variance of the initial weights (weight coefficient of variance $(\mathrm{CV})=$ standard deviation x 100/mean). Fish were selected visually from the initial pool to provide low and high initial variability respectively in size, resulting in low variability groups with coefficients of variance of $0.0 \pm 0.0 \%$ and high variability groups with coefficients of variance of $58.2 \pm 2.8 \%$. The two stocking densities used were $0.5 \mathrm{fish} / \mathrm{L}$ and $2 \mathrm{fish} / \mathrm{L}$. The fish were weighed at the beginning of the experiment after 8, 16, 22 and 30 days.

\section{Statistical analysis}

An analysis of variance was carried out on weight measurements, followed by Tukey's multiple comparison test for comparison of means. Median coefficients of variance were compared with Kruskal-Wallis non-parametric test followed by pair-wise comparisons with Dunn's multiple comparison test (ESTAT - FRAGPD Program) 


\section{RESULTS}

\section{Weight gain}

Initial weight of the animals in all treatment groups was similar and all showed significant growth during the experiment. However, there were significant differences in weight gain at 16 days $\left.\left(\mathrm{F}_{(3: 20}\right)=6.37, * * \mathrm{P}<0.01\right), 22$ days $\left(\mathrm{F}_{(3: 20}\right)=6.66$, $* * \mathrm{P}<0.01)$, and at 30 days $\left(\mathrm{F}_{(3: 20)}=7.25\right.$, $* * \mathrm{P}<0.01$ ) between the treatment groups (Fig. 1).

At 16 days, these differences represent significant differences in the lower weight of the high density, highly variable group (1) and the higher weight of the low density, low variability group (4). At 30 days, the weights of the two low density groups, of both high and low initial variability, were indistinguishable but significantly different from the high density, highly variable group (1).

\section{Heterogeneous growth (HetG)}

As defined by the experimental design, conditions 2 and 4 had high initial variability in weight, whereas conditions 1 and 3 did not. At 8 and 16 days, the coefficient of variance in weight had increased significantly in conditions 1 and 3 and decreased in conditions 2 and 4 (Fig. 2),

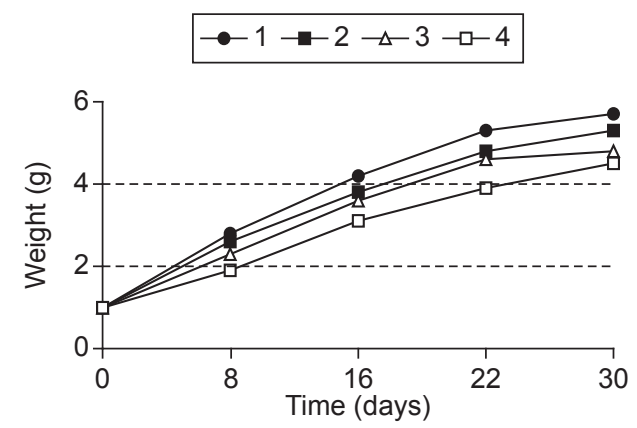

Fig. 1 - Weight gain of Oreochromis niloticus in four experimental courses of treatment: 1 = low initial variability size and low density; 2 = high initial variability size and low density; 3 = low initial variability size and high density; and $4=$ high initial variability and high density. Low variability: $\mathrm{CV}=0.0 \pm 0.0$ and high variability: $\mathrm{CV}=58.2 \pm 2.8$. Low density $=1$ fish/2 L of water and high density $=1 \mathrm{fish} / 0.5 \mathrm{~L}$ of water.

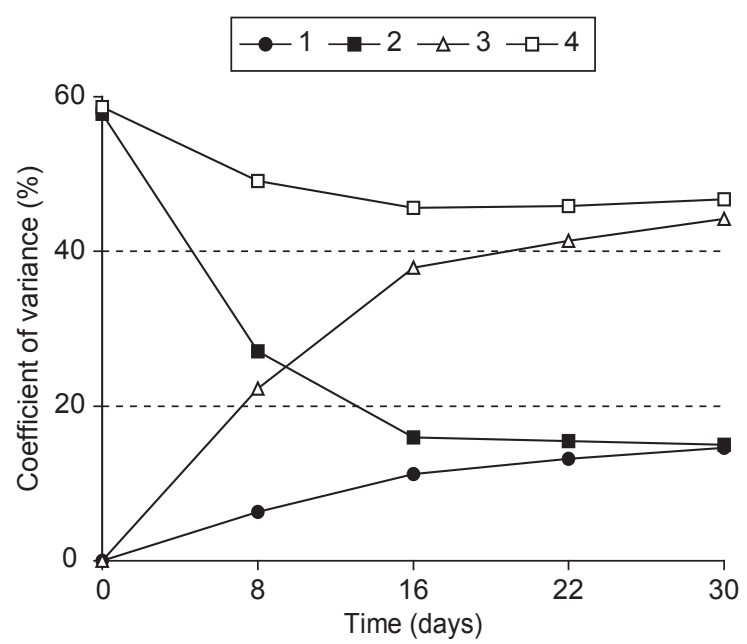

Fig. 2 - Heterogeneous growth of Oreochromis niloticus in four experimental courses of treatment: $1=$ low initial variability size and low density; 2 = high initial variability size and low density; $3=$ low initial variability size and high density; and $4=$ high initial variability and high density. Low variability: $\mathrm{CV}=0.0 \pm 0.0$ and high variability: $\mathrm{CV}=58.2 \pm 2.8$. Low density $=$ $1 \mathrm{fish} / 2 \mathrm{~L}$ of water and high density $=1 \mathrm{fish} / 0.5 \mathrm{~L}$ of water. 
whereas no further significant change occurred between 16, 22 and 30 days.

The main changes in variability after 8 and 16 days consisted of a marked increase in variability in the initial low variability/high density group (condition 4) and a marked decrease in variability in the initially highly variable/low density group (condition 1; ***P $<0.001$ with Dunn's pair-wise comparison).

\section{Behavioral observations}

Behavior of the tilapia fingerling in the study aquaria was quite uniform throughout the experiment, similar to the behavior of curimatá (Prochilodus lineatus) fingerlings (Barbosa, 1997). All fish remained primarily on the bottom of the aquarium, with one individual occupying each corner. Social hierarchy consisted of one dominant fish, two of secondary dominance, and a fourth subordinate individual. Approximation of a corner by another individual resulted in aggressive interaction and the results were determined by the social hierarchy. Dominance was generally indicated by displaying a raised dorsal fin, at times followed by physical interaction. Spatial separation and social interaction decreased at the surface during feeding, but was evident during subsequent feeding on the bottom of the aquarium. However, surplus food was always present, so even the subordinate individuals were apparently fed to satiation. Similar behavior was observed in the aquaria of both sizes.

\section{DISCUSSION}

We have demonstrated here that in the presence of surplus food, low stocking density results in low heterogeneous growth in Oreochromis niloticus fry with both high and low initial variability in fish size, whereas high stocking density results in increased or continued high levels of heterogeneous growth. These results are compatible with data presented by Ito \& Barbosa (1997) who reported a reduction in HetG in juveniles of mullet Mugil platanus of high initial growth differences that were moved to lower stocking densities. In contrast, heterogeneous growth is generally thought to result from competition for a sparse supply of adequate food, which often coincides with increased fish densities. We thus propose that social components or other non-food related effects of crowding are also significant determinants of heterogeneous growth in $O$. niloticus. Furthermore, we have found that reducing the crowding effects can eliminate size variability from previous heterogeneous growth. Compensatory growth was reported earlier for fish after removal from growth-limiting situations, and is probably responsible for the equalisation of fish sizes in the unclouded situation in our experiments. What is interesting is that we worked with very small groups of fish, fed ad libitum, and altered stocking density not by increasing the number of fish but rather by decreasing the size of the aquarium. Social factors involved in regulating heterogeneity of growth in our experiments, thus, are evident even in small groups and are enhanced through either decreased water volume and/or closer interaction between individuals. Chronic stress has been reported to occur in subordinate individuals of a social hierarchy (Peters et al. 1978), and Refstie \& Kittelsen (1976), Refstie (1977), Kjartansson et al. (1988) indicate that this can lead to reduced growth.

We also observed in our study that groups of fry of initially highly different weights placed in a crowded situation (small aquaria) did not increase in variability, in contrast to assertions by Brown (1946), Nakamura \& Kasahara (1955; 56; 57 and 61), Yamagishi (1969), Wohlfarth (1977), Volpato et al. (1989), and Barbosa (1997) who claim that crowding generally results in increased heterogeneity in growth. As the variability in size at the beginning of the experiment was determined artificially by active selection, it is unlikely that the lack of increased heterogeneity is due to a similarity between the stocking density in the source tank and the experimental tanks. Rather, it is likely that once heterogeneous growth rates have been established, they may remain relatively constant. In contrast, when initial heterogeneity in size is reduced by selecting appropriately-sized fish for the experiment (as is commonly done), "secondary shooting" (Wohlfarth, 1977) may result in apparently increased heterogeneous growth. One course of treatment in our experiments (low initial weight variability and high density) also showed this result. However, the lack of increased heterogeneity in the crowded treatment that started with heterogeneous fish samples suggests that the increase in heterogeneous growth in crowded 
situations that is often reported may actually reflect a release of growth potential in newly dominant individuals, rather than be a direct effect of crowding.

Heterogeneous growth of $O$. niloticus fingerling can be reduced, maintained or increased by social or physical effects of stocking densities in the presence of excess food. Crowding tended to increase heterogeneous growth in initially homogeneous groups of fish, but maintained, rather than increased, heterogeneous growth of groups of fish that were already of heterogeneous size. Low stocking densities, on the other hand, reduced the variability in size of initially heterogeneous fish groups.

Acknowledgments - The authors are indebted to Drs. Ivanzir Vieira from the Universidade Federal de Juiz de Fora, Paulo R. Leme, Prabir K. Chandra and Luis Roberto A de Toledo from the Universidade de São Paulo, for the text review.

\section{REFERENCES}

ALLEN, G. R., 1972, The anemonefish: their classification and biology. T. F. H. Publications, Neptune City, 228p.

BARBOSA, J. M., 1997, Variação intraespecífica no crescimento de peixes: modulação química e hábito social, 39p., Instituto de Biociências, UNESP, Botucatu (Doctor's Thesis).

BROWN, M. E., 1946, The growth of brown trout (Salmo trutta L.): I. Factors influencing the growth of trout fry. J. Exp. Biol., 22: 118-129.

DAVIS, M. W. \& OLLA, B. L., 1987, Aggression and variation in growth of chum salmon (Onchorhynchus keta) juveniles in seawater: effects of limited rations. Can. J. Fish. Aq. Sci., 44: 192-197.

FERNANDES, M. O. \& VOLPATO, G. L., 1994, Heterogeneous growth in the Nile tilapia: social stress and carbohydrate metabolism. Physiol. Behav., 54: 319-323.

ITO, K. \& BARBOSA, J. M.,1996, Crescimento heterogéneo em tainha Mugil platanus: influência de níveis proteicos na ração. Actas do Congresso Português de Engenheiros Zootécnicos, Évora, 6(2): 477-480.

JOBLING, M. \& WANDSVICK, A., 1983, Effect of social interactions on growth rates and conversion efficiency of Arctic charr, Salvelinus alpinus L. J. Fish. Biol., 22: $577-584$.
KJARTANSSON, H., SVEINUNG F., THOMASSEN, J. M. \& SMITH, M. J., 1988, Effects of different stocking on physiological parameters and growth of adult Atlantic Salmon (Salmo salar L.) reared in circular tanks. Aquaculture, 73: 261-274.

KOEBELE, B. P., 1985, Growth and size hierarchy effect: an experimental assessment of three proposed mechanisms; activity differences, disproportional food acquisition, physiological stress. Environ. Biol. Fish., 12: 181-188.

NAKAMURA, N. \& KASAHARA, S., 1955, A study on the phenomenon of tobi-koi or shoot carp. I. On the earliest stage at which the shoot carp appears. Bull. Jpn. Soc. Sci. Fish., 21: 73-76 (translated in Bamidgeh, 29: 41-44, 1977).

NAKAMURA, N. \& KASAHARA, S., 1956, A study on the phenomenon of tobi-koi or shoot carp. II. On the effect of particle size and quantity of the food. Bull. Jpn. Soc. Sci. Fish., 21: 1022-024. (translated in Bamidgeh, 29: 44-47, 1977).

NAKAMURA, N. \& KASAHARA, S., 1957, A study on the phenomenon of tobi-koi or shoot carp. III. On the results of culturing the modal group and the growth of carp fry reared individually. Bull. Jpn. Soc. Sci. Fish., 22: 674-678. (translated in Bamidgeh, 29: 48-52, 1977).

NAKAMURA, N. \& KASAHARA, S., 1961, A study on the phenomenon of tobi-koy or shoot carp. IV. Effects of adding small number of larger individual to the experimental batches of carp fry and culture density upon the occurrence of shoot carp. Bull. Jpn. Soc. Sci. Fish., 27: 958-962. (translated in Bamidgeh, 29: 53-56, 1977).

PETERS, G., DELVENTHAL, H. \& KLINGER, H., 1978, Physiological and morphological effects of social stress in the eel (Anguilla anguilla L.). Arch. Fischer., 30(2/3): 157-180.

REFSTIE, T., 1977, Effects of density on growth and survival of rainbow trout. Aquaculture, 11: 329-334.

REFSTIE, T. \& KITTELSEN, A., 1976, Effects of density on growth and survival of artificial reared Atlantic salmon. Aquaculture, 8: 319-326.

VOLPATO, G. L. \& FERNANDES, M. O., 1994, Social control of growth in fish. Braz. J. Med. Biol. Res., 27: 797-810.

VOLPATO, G. L., FRIOLI, P. M. A. \& CARRIERI, M. P., 1989, Heterogeneous growth in fishes: some new data of Nile tilapia Oreochromis niloticus and a general view about the causal mechanisms. Bol. Fisiol. An. São Paulo, 13: 7-22.

WOHLFARTH, G. W., 1977, Shoot carp. Bamidgeh, 29(2): 35-40,

YAMAGISHI, H., 1969, Postembryonal growth and its variability of the three fishes with special reference to the mechanism of growth variation in fishes. Res. Pop. Ecol., 1: 14-33. 